ljtihad, Jurnal Wacana Hukum Islam dan Kemanusiaan

Vol. 17, No. 1 (2017), pp. 113-133, doi : 10.18326/ijtihad.v17i1.113-133

\title{
Isbat nikah terpadu sebagai solusi memperoleh hak identitas hukum
}

\author{
Ramdani Wahyu Sururie \\ Universitas Islam Negeri Sunan Gunung Djati Bandung \\ Jl. AH. Nasution Nomor 105 Cibiru Bandung \\ Email:ramdani.wabyu@uinsgd.ac.id \\ doi : 10.18326/ijtihad.v17i1.113-133
}

The integrated marriage isbat is a series of activity which is jointly conducted and coordinated within particular time and place between the Religious Court/Court of Law, the Regional Office of Citizenship Service in a city or a district, the sub-district Office of Religious Affairs with its mobile service for giving the marriage legalization. The integrated marriage isbat is conducted based on the rules of the Supreme Court, Number 1 in 2015. Even though the legal basis of such integrated marriage isbat is under the rules of the Supreme Court, yet the function remains the same that is the regulatory function or regelende functie for the continuity of judicature implementation. The background of the issue of the Supreme Court Rules Number 1 in 2015 is that there are so many numbers of marriages which are not registered because of the society's lacking access to the courts. The aim of the integrated marriage isbat is to improve the access toward legal service and to help people, especially those who haves not, in obtaining the rights of marriage certificate, the excerpt of marriage certificate, and the birth certificate as simple, fast, and cheap as possible. Principally, the implementation of the integrated marriage isbat is similar to the regular one conducted in the court; what make it different are that the place is outside the court, free of charge, single judge, and collective vacation. Therefore it can be concluded then that the implementation of the integrated marriage isbat is to fulfill the rights in obtaining law identity for those who haves not as the solution for the law assurance.

Isbat nikah terpadu adalah rangkaian kegiatan yang dilakukan bersama-sama dan ter-kor-dinasi dalam satu waktu dan tempat tertentu antara Pengadilan Agama/Mahkamah Syar'iyyah, Dinas Kependudukan dan Pencatatan Sipil Kabupaten/Kota, KUA dalam layanan keliling untuk memberikan pelayanan pengesahan perkawinan. Isbat nikah terpadu dilaksanakan berdasarkan Peraturan Mahkamah Agung Nomor 1 Tahun 2015. Sekalipun dasar hukum pelaksanaan Isbat nikah terpadu tersebut dipayungi oleh Perma, namun fungsinya tetap sama yaitu fungsi pengaturan atau regelende functie bagi kelancaran penyelenggaraan peradilan. Latar belakang lahirnya Perma Nomor 1 Tahun 2015 karena tingginya angka perkawinan yang tidak dicatat disebabkan lemahnya akses masyarakat tidak mampu ke pengadilan. 
ljtihad, Jurnal Wacana Hukum Islam dan Kemanusiaan, Volume 17, No. 1, Juni 2017: 113-133

Tujuan diberlakukan isbat nikah terpadu adalah untuk meningkatkan akses terhadap pelayanan di bidang hukum dan membantu masyarakat terutama yang tidak mampu dalam memperoleh hak atas akta perkawinan, buku nikah dan akta kelahiran yang dilakukan secara sederhana, cepat dan biaya riangan. Secara prinsip, pelaksanaan isbat nikah terpadu sama dengan isbat nikah reguler yang dilaksanakan di pengadilan. Yang membedakannya adalah tempat di luar pengadilan, biaya nihil, hakim tunggal dan pemangilannya kolektif. Dengan demikian dapat disimpulkan bahwa terselenggaranya isbat nikah terpadu ini dalam rangka memenuhi hak memperoleh identitas hukum berupa akta nikah bagi masyarakkat yang tidak mampu sebagai solusi yang diberikan negara agar memperoleh kepastian hukum.

Keywords: integrated marriage isbat; religious court; compilation of Islamic law; Perma No. 1 2015; legal identity

\section{Pendahuluan}

Isbat Nikah diartikan sebagai penetapan tentang sahnya suatu perkawinan. Isbat Nikah merupakan penggabungan dua kata, yang terdiri dari kata isbat dan Nikah. Kedua kata itu berasal dari bahasa Arab, yakni dari akar kata “athbata, yuthbitu, ithbätan” Artinya menetapkan/ penetapan. Isbat kata benda $(\mathrm{kb})$ 'berarti' penetapan, penentuan. Sementara perkawinan adalah terjemahan dari kata "nikēh" dan kata "zawäj”. Nikah menurut bahasa mempunyai arti yang asli (haqiqat) yakni "dam” yang berarti menghimpit, menindih, atau berkumpul. Nikah mempunyai pula arti kiasan yakni "wata'd” yang berarti "setubuh" atau "aqad" yang berarti mengadakan perjanjian pernikahan (Amin, 2012: 23).

Istilah isbat terpadu diidentikan dengan pelayanan terpadu yang dilaksanakan oleh Pengadilan Agama. Menurut Perma Nomor 1 Tahun 2015 tentang Pelayanan Terpadu Sidang Keliling Pengadilan Negeri dan Pengadilan Agama/Mahkamah Syar'iyyah dalam Rangka Penerbitan Akta Perkawinan, Buku Nikah dan Akta Kelahiran, pelayanan terpadu adalah rangkaian kegiatan yang dilakukan secara bersama-sama dan terkordinasi dalam satu waktu dan tempat tertentu antara Pengadilan Negeri atau Pengadilan Agama/Mahkamah Syar'iyyah, Dinas Kependudukan dan Pencatatan Sipil Kabupaten/Kota, KUA dalam layanan keliling untuk memberikan pelayanan pengesahan perkawinan dan perkara lainnya sesuai dengan kewenangan PN dan isbat nikah sesuai dengan kewenangan Pengadilan Agama/ Mahkamah Syar'iyyah dan untuk memenuhi pencatatan perkawinan dan pencatatan kelahiran.

Berdasarkan pengetian pelayanan terpadu dalam Perma Nomor 1 Tahun 2015, maka istilah isbat nikah terpadu merupakan sidang penetapan perkawinan yang dilaksanakan secara 
bersama-sama (terpadu) dengan beberapa instansi terkait, yaitu Pengadilan Agama, KUA dan Disdukcapil. Sidang isbat terpadu ini sering juga dinamakan sidang isbat satu atap.

Isbat nikah terpadu berhubungan erat dengan hak identitas hukum setiap warga negara. Dengan memperoleh akta perkawinan dalam isbat nikah terpadu, seseorang yang tadinya tidak memiliki identitas hukum, akan memperoleh identitas hukum berupa akta nikah sehingga isbat nikah terpadu merupakan kebijakan negara bagi masyarakat guna memperoleh identitas hukum.

Sejumlah data menunjukkan bahwa jumlah perkara Isbat nikah (penetapan perkawinan) di 359 Pengadilan Agama di Indonesia naik tiga kali lipat. Di tahun 2013 misalnya, Pengadilan Agama menyidangkan lebih dari 35.000 perkara Isbat nikah. Jumlah perkara yang disidangkan melalui sidang keliling di tingkat desa naik dua kali lipat dan Pengadilan Agama menyidangkan lebih dari 23.000 perkara melalui sidang keliling di tahun 2012 (Sumner, 2013: 9). Selama tahun 2014 telah dilaksanakan layanan sidang terpadu pada 14 wilayah pengadilan tinggi agama yang tersebar di 161 lokasi. Adapun pelaksanaannya dilakukan sebanyak 196 kali dengan jumlah perkara yang diselesaikan sebanyak 7.398 perkara (Anonimouos, 2014: 50). Data ini menunjukkan bahwa keterlibatan pengadilan agama di dalam melayani hak identitas hukum sangat besar sehingga cukup beralasan apabila dikemudian hari terdapat suatu mekanisme yang mempermudah masyarakat miskin memperoleh hak identitas hukum tersebut.

Sekalipun isbat nikah kedudukan hukumnya dalam sistem hukum perkawinan di Indonesia masih menjadi polemik, namun tulisan ini tidak akan banyak mengulas dimensi polemik hukum tersebut, tetapi berhasrat melakukan analisis deskriptif mengenai peranan isbat nikah terpadu dalam membuka ruang bagi masyarakat tidak mampu (secara finansial dan pengetahuan) memiliki identitas hukum guna terciptanya kepastian hukum terhadap status anak dari hasil perkawinan mereka yang tidak tercatat.

\section{Dasar hukum isbat nikah terpadu}

Dasar pemberlakuan Isbat nikah terpadu adalah Perma Nomor 1 Tahun 2015 tentang Pelayanan Terpadu Sidang Keliling Pengadilan Negeri dan Pengadilan Agama/Mahkamah Syar'iyah dalam Rangka Penerbitan Akta Perkawinan, Buku Nikah dan Akta Kelahiran. 
ljtihad, Jurnal Wacana Hukum Islam dan Kemanusiaan, Volume 17, No. 1, Juni 2017: 113-133

Sebelum Perma ini lahir, berbagai kebijakan MA yang terkait dengan Isbat nikah terpadu adalah Surat Edaran Ketua Mahkamah Agung Nomor 10 Tahun 2010, lampiran B tentang Pedoman Pemberian Bantuan Hukum di lingkungan Peradilan Agama yang telah diubah dengan Perma Nomor 1 Tahun 2014 tentang Pedoman Pemberian Layanan Hukum bagi Masyarakat Tidak Mampu, Keputusan Bersama Ketua Muda Urusan Lingkungan Peradilan Agama dan Sekretaris Mahkamah Agung RI Nomor 04/TUADA-AG/II/2011 dan nomor 020/SEK/SK/II/2011 tentang Petunjuk Pelaksanaan Surat Edaran Mahkamah Agung RI Nomor 10 Tahun 2010 tentang Pedoman Bantuan Hukum Lampiran B dan SK KMA No 26 Tahun 2012 tentang Standar Pelayanan Peradilan dan Sema Nomor 3 Tahun 2014 tentang Tata Cara Pelayanan dan Pemeriksaaan Perkara Voluntair Isbat Nikah dalam Pelayanan Terpadu.

Pertimbangan lahirnya Perma Nomor 1 Tahun 2015 ini adalah bahwa setiap orang berhak mendapatkan pengakuan hukum tanpa diskriminasi termasuk hak membentuk keluarga dan keturunan melalui perkawinan yang sah (yang dibuktikan dengan akta perkawinan) dan hak anak atas identitas diri yang dituangkan dalam akta kelahiran. Namun, bagi sebagian masyarakat miskin, guna memperoleh hak identitas hukum tersebut menghadapi hambatan biaya, jarak dan waktu dalam menyelesaikan proses pencatatan perkawinan dan pencatatan kelahiran. Guna meningkatkan pelayanan terhadap masyarakat miskin dalam memperoleh akta perkawinan, buku nikah dan akta kelahiran, maka Mahkamah Agung memandang perlu untuk melakukan koordinasi dengan Kementerian Dalam Negeri dan Kementerian Agama untuk menetapkan Peraturan Mahkamah Agung tentang Pedoman Pelayanan Terpadu Sidang Keliling PN, PA/MS dalam rangka penerbitan akta perkawinan, buku nikah dan akta kelahiran.

Potret masyarakat yang tidak memperoleh hak identitas hukum berupa akta nikah sebagaimana digambarkan di atas telah mendorong Mahkamah Agung untuk kemudian membuat kebijakan yang disebut justice for all (keadilan bagi semua). Berbagai langkah sudah dilakukan mulai dari kebijakan adanya Posbakum, sidang di luar pengadilan (sidang keliling) dan yang terakhir adalah sidang Isbat terpadu. Maka terbitlah SEMA Nomor 3 Tahun 2014 yang mengatur tentang pelaksanaan Isbat terpadu yang kemudian diikuti oleh peraturan yang lebih teknis dan rinci melalui pedoman pelaksanaan sidang keliling yang diterbitkan 
oleh beberapa Pengadilan Tinggi Agama. SEMA ini kemudian berubah sejak bulan Agustus 2015, menjadi Perma Nomor 1 Tahun 2015 sehingga Sema Nomor 3 Tahun 2014 dicabut dan dinyatakan tidak berlaku.

Sekalipun dasar hukum pelaksanaan Isbat nikah terpadu tersebut dipayungi oleh Perma, namun fungsinya tetap sama yaitu fungsi pengaturan atau regelende functie. Perma merupakan produk Mahkamah Agung. Untuk melihat produk-produk hukum Mahkamah Agung ("MA"), harus dilihat bagaimana peraturan perundang-undangan mengatur dan memberi kewenangan kepada MA. Pasal 24 A Undang-Undang Dasar RI 1945 mengatur MA berwenang mengadili pada tingkat kasasi, menguji peraturan perundang-undangan di bawah undang-undang terhadap undang-undang, dan mempunyai wewenang lainnya yang diberikan undang-undang. Ini juga sejalan dengan pandangan bahwa peraturan perundang-undangan hanya dapat dibentuk oleh lembaga-lembaga yang memperoleh kewenangan perundangundangan (wetgevingsbevoegheid), yaitu kekuasaan untuk membentuk hukum atau rechtsvorming (Farida, 1998:54).

Ada beberapa kewenangan dan tugas yang diberikan Undang-Undang kepada Mahkamah Agung, antara lain: Pertama, Mahkamah Agung memberikan pertimbangan hukum kepada Presiden dalam permohonan grasi dan rehabilitasi (Pasal 14 ayat 1 UUD jo Pasal 35 Unangundang Mahkamah Agung. Kedua, Mahkamah Agung dapat memberikan pertimbanganpertimbangan dalam bidang hukum baik diminta maupun tidak kepada lembaga tinggi negara yang lain (Pasal 37 Undang-undang Mahkamah Aagung). Ketiga, Mahkamah Agung berwenang memberikan petunjuk di semua lingkungan peradilan dalam rangka pelaksanaan ketentuan Undang-Undang Kekuasaan Kehakiman (Pasal 38 Undang-Undang Mahkamah Agung). Keempat, Mahkamah Agung berwenang memberikan petunjuk, teguran, atau peringatan yang dipandang perlu kepada pengadilan di semua lingkungan peradilan.

Kewenangan dan tugas demikian disebut sebagai fungsi pengaturan atau regelende functie Mahkamah Agung. Ini juga sejalan dengan rumusan Pasal 79 Undang-undang Mahkamah Agung, yang mengatur "Mabkamah Agung dapat mengatur lebih lanjut hal-hal yang diperlukan bagi kelancaran penyelenggaraan peradilan apabila terdapat hal-hal yang belum cukup diatur dalam UndangUndang ini" (Pangabean, 2001: 143). Dalam konteks itulah dapat dibaca produk hukum MA itu sebagai berikut: (i) PERMA; (ii) SEMA; (iii) Fatwa; dan (iv) SK KMA. 
ljtihad, Jurnal Wacana Hukum Islam dan Kemanusiaan, Volume 17, №. 1, Juni 2017: 113-133

Peraturan MA atau PERMA pada dasarnya adalah bentuk peraturan yang berisi ketentuan bersifat hukum acara. Sedangkan, Surat Edaran MA atau SEMA bentuk edaran pimpinan MA ke seluruh jajaran peradilan yang berisi bimbingan dalam penyelenggaraan peradilan, yang lebih bersifat administrasi). Fatwa MA berisi pendapat hukum MA yang diberikan atas permintaan lembaga negara. Surat Keputusan Ketua MA atau SK KMA adalah surat keputusan (beschikking) yang dikeluarkan Ketua MA mengenai satu hal tertentu.

Keabsahan produk-produk hukum MA tersebut bisa dirujuk pada UU No. 10 Tahun 2004 tentang Pembentukan Peraturan Perundang-Undangan yang telah diganti dengan UU No. 12 Tahun 2011 tentang Pembentukan Peraturan Perundang-Undangan. Pasal 8 ayat (1) Undang-Undang Nomor 12 Tahun 2011 mengatur: "Jenis peraturan perundang-undangan selain yang disebut dalam Pasal ayat (1) mencakup peraturan yang ditetapkan...Mabkamah Agung...". Rumusan ini senafas dengan Pasal 7 ayat (4) dan penjelasan Undang-Undang Nomor 10 Tahun 2004. Selanjutnya, Pasal 8 ayat (2) Undang-Undang Nomor 12 Tahun 2011 menegaskan peraturan perundang-undangan tersebut diakui keberadaannya dan mempunyai kekuatan hukum mengikat sepanjang diperintahkan oleh peraturan perundang-undangan yang lebih tinggi atau dibentuk berdasarkan kewenangan (Hurairah, 2015: 259).

\section{Latar belakang dan tujuan isbat nikah terpadu}

Latar belakang lahirnya Perma Nomor 1 Tahun 2015 ini didahului oleh studi dan penelitian terutama yang terkait dengan akses masyarakat tidak mampu untuk memperoleh hak hukum atau identitas hukum berupa akta nikah. Awal penelitian dilakukan sejak tahun 2006 antara AIPJ (Australia Indonesia Parthership for Justice), PUSKAPPA (Pusat Kajian dan Perlindungan Anak) dan Pekka (Perempuan Kepala Keluarga) dengan Mahkamah Agung mengenai pentingnya peningkatan kesadaran masyarakat untuk memperoleh layanan keadilan bagi perempuan, masyarakat miskin, dan warga di daerah terpencil. Layanan keadilan tersebut yaitu memproleh hak identitas hukum yang sesungguhnya bisa dilayani oleh dunia peradilan, seperti misalnya perceraian dan pengesahan perkawinan (Isbat nikah).

Studi dasar itupun menunjukkan bahwa pada rumah tangga yang termasuk 30\% termiskin mayoritas pasangan (55\%) tidak memiliki akta/buku nikah, dan 75\% anak-anak mereka tidak memiliki akta kelahiran. SUSENAS dan studi dasar ini menegaskan pula bahwa alasan 
utama seseorang tidak memiliki dokumen identitas hukum seperti misalnya akta kelahiran atau akta/buku nikah ialah (i) mahalnya biaya untuk memperoleh dokumen tersebut (41\%); (ii) jauhnya jarak ke kantor layanan (15\%); dan (iii) kurangnya pemahaman tentang cara memperoleh dokumen tersebut $(12 \%)$, serta (iv) rumitnya proses yang harus dijalani ( $9 \%$ ). Biaya Isbat nikah (pengesahan perkawinan) dan perkara cerai gugat (cerai yang diajukan pihak istri) di Pengadilan Agama bisa mencapai 1 hingga 10 kali lipat pendapatan bulanan seseorang yang hidup pada garis kemiskinan Indonesia, tergantung pada seberapa jauh lokasi pengadilan dari tempat tinggal para pihak.

Kemudian pada tahun 2011, Kementerian Agama mencatat sebanyak 2.207.364 pernikahan di Indonesia dan kurang dari 50\% pasangan di Indonesia memiliki akta/buku nikah, maka diperkirakan bahwa tiap tahun ada lebih dari 2 juta pasangan di Indonesia yang tidak mencatatkan pernikahan mereka. Dampak tersembunyi dari pernikahan yang tidak dicatatkan ialah bahwa anak-anak dari pernikahan tersebut tidak dapat memiliki akta kelahiran yang mencantumkan nama ayah dan ibu mereka (Cate Sumner, 2013: 12).

Kehadiran isbat nikah terpadu merupakan jawaban atas potret masyarakat, khususnya masyarakat tidak mampu untuk memperoleh identitas hukum. Identitas hukum ini menjadi penting, utamanya akta nikah karena akta nikah ini merupakan induk dari dokumen hukum lainnya berupa akta kelahiran. Pasangan suami isteri yang tidak memiliki identitas hukum berupa akta perkawinan tidak akan memperoleh akta kelahiran bagi anaknya sehingga status anak pun menjadi tidak jelas. Terbitnya akta nikah dalam pelaksanaan isbat nikah terpadu akan membuka jalan dan akses terhadap fasilitas pendidikan, kesehatan, sosial, ekonomi, dan lainnya.

Tujuan diberlakukan isbat nikah terpadu sebagaimana dirumuskan di dalam Perma Nomor 1 Tahun 2015 pasal 2 yaitu untuk meningkatkan akses terhadap pelayanan di bidang hukum dan membantu masyarakat terutama yang tidak mampu dalam memperoleh hak atas akta perkawinan, buku nikah dan akta kelahiran yang dilakukan secara sederhana, cepat dan biaya riangan.

Perma Nomor 1 Tahun 2015 memberi jawaban bagi terbukanya akses pelayan dibidang hukum. Menurut Hasbi Hasan (2015: 1), berdasarkan data penelitian, lebih dari 50 juta penduduk Indonesia tidak memiliki buku nikah dan akta kelahiran dan lebih dari 700.000 WNI di luar negeri seperti Saudi Arabia, Malaysia, Mesir bahkan di Amerika tidak memiliki 
ljtihad, Jurnal Wacana Hukum Islam dan Kemanusiaan, Volume 17, No. 1, Juni 2017: 113-133

identitas hukum. Bisa dibayangkan, masyarakat Indonesia tanpa identitas hukum berupa akta nikah sangat sulit memperoleh akses layanan pendidikan, kesehatan dan ekonomi. Oleh karena itu, guna mempercepat akses pelayanan di bidang hukum, maka dilakukanlah sidang isbat nikah di luar pengadilan sebagaimana Perma Nomor 1 Tahun 2015 yang dilaksanakan secara terpadu (integrated services) dan selesai dalam satu hari (one day service) oleh pengadilan agama, KUA dan Dinas Dukpencapil (Husaini, 2015: 2).

\section{Proses isbat nikah terpadu: pengalaman beberapa pengadilan agama}

Proses pemeriksaan Isbat nikah terpadu pada dasarnya sama dengan proses pemeriksaan Isbat nikah pada umumnya. Yang membedakan sidang Isbat nikah terpadu dengan perkara Isbat lainnya adalah terletak pada (1) penyelenggaraan sidang Isbat nikah terpadu dilaksanakan secara kolektif sedangkan Isbat nikah biasa secara pribadi, (2) Instansi yang terlibat terdiri atas Pengadilian Agama, Kemenag/KUA, Pemda/Disdukcapil, sedangkan Isbat nikah biasa hanya melibatkan Pengadilan Agama, (3) Tempat penyelenggaraan sidang Isbat nikah terpadu bisa menggunakan ruang sidang Pengadilan Agama, tetapi pada umumnya dilaksanakan di luar pengadilan dalam bentuk sidang keliling yang tempatnya bisa di Pemda, Gedung Serba Guna, Kecamatan dan tempat lain yang refresentatif untuk sidang, sedangkan untuk sidang Isbat biasa dilaksanakan di pengadilan dan (4) terdapat hal-hal khusus lainnya misalnya perkara yang diajukan dalam Isbat nikah terpadu hanya Isbat nikah dalam bentuk voluntair, hakimnya boleh tunggal, dan panggilan kepada para pihak bisa dilakukan secara kolektif, sedangkan Isbat nikah biasa dilakukan dengan cara voluntair dan kontentius, hakimnya majelis dan panggilan tidak dilakukan secara kolektif.

Pelaksanaan Isbat nikah dilakukan dalam sidang di luar pengadilan (sidang keliling) sesuai dengan SK KMA Nomor 26 Tahun 2012 tentang Standar Pelayanan Peradilan Agama dalan poin $G$ dinyatakan "Semua perkara pada dasarnya dapat diajukan melalui sidang keliling, akan tetapi karena keterbatasan pada pelayanan sidang keliling, maka perkara yang dapat diajukan melalui sidang keliling, di antaranya adalah Isbat nikah (pengesahan/pencacatan nikah) bagi pernikahan yang tidak terdaftar di KUA.

Dilihat dari segi biaya, sidang Isbat nikah terpadu dan sidang Isbat nikah biasa dapat menggunakan biaya sendiri, biaya dari Pemda, Prodeo ataupun dari DIPA Pengadilan 
Agama. Namun pada umumnya, pihak yang ikut serta dalam sidang Isbat terpadu adalah orang-orang yang tidak mampu secara finansial. Sekalipun demikian, masyarakat yang mampu pun jika Pengadiilan Agama dengan tempat tinggal sangat jauh dapat memanfaatkan sidang Isbat nikah terpadu ini.

Secara khusus, Perma Nomor 1 Tahun 2015 mengatur ketentuan sidang Isbat nikah terpadu dalam pasal 12, yaitu: Pertama, perkara isbat nikah yang dilayani oleh Pengadilan Agama/Mahkamah Syar'iyah dalam pelayanan terpadu adalah perkara isbat nikah yang bersifat permohonan (volluntair); Kedua, sidang permohonan isbat nikah dihadiri oleh pasangan suami isteri yang masih hidup secara pribadi (in person) kecuali ada alasan lain; Ketiga, dalam hal salah satu pasangan atau keduanya sudah meninggal, permohonan isbat nikah tidak dapat dilaksanakan pada pelayanan terpadu; Keempat, pemeriksaan permohonan isbat nikah dalam pelayanan terpadu dapat dilaksanakan oleh hakim tunggal; Kelima, tata cara sidang di luar gedung pengadilan dilaksanakan berdasarkan ketentuan yang berlaku; Keenam, dalam menjalankan tugasnya, hakim tersebut dibantu oleh 1 (satu) orang panitera pengganti, 1 (satu) orang juru sita/juru sita pengganti dan sekurang-kurangnya 1 (satu) orang petugas administrasi; Ketujuh, pemanggilan pemohon yang jumlahnya lebih dari satu dapat dilakukan dengan diumumkan oleh pemerintah daerah dan papan penguman pengadilan setelampat atau media lainnya yang dimiliki oleh pengadilan; Kedelapan, pelaksanaan sidang dalam pelayanan terpadu dilakukan sesuai dengan ketentuan yang berlaku; Kesembilan, pelayanan terpadu dapat dilaksanakan bersamaan dengan : a. Layanan pos bantuan hukum dan atau b. Sidang reguler

Terlihat dengan jelas bahwa di dalam Perma tersebut mengatur suatu kebijakan mengenai pelaksanaan sidang Isbat nikah terpadu yang tidak diatur di dalam undang-undang. Secara khusus Perma itu mengatur bahwa sidang Isbat nikah terpadu hanya dilaksanakan pada bentuk permohonan (voluntair) di mana yang mengajukan Isbat nikah adalah suami isteri. Jika yang mengajukan hanya suami atau isteri, maka isteri atau suami harus didudukan sebagai termohon. Berarti perkaranya termasuk perkara contentius. Dalam kasus yang demikian, tidak akan dilayani dalam sidang Isbat nikah terpadu. Termasuk dalam hal ini apabila salah satu pihak atau kedua pihak telah meninggal dunia tidak bisa dilakukan dalam pelayanan terpadu. 
ljtihad, Jurnal Wacana Hukum Islam dan Kemanusiaan, Volume 17, No. 1, Juni 2017: 113-133

Sesuai dengan ketentuan yang diatur dalam Buku II menyatakan bahwa "proses pemeriksaan permohonan Isbat nikah yang diajukan oleh salah seorang suami atau isteri bersifat kontensius dengan mendudukkan isteri atau suami yang tidak mengajukan permohonan sebagai pihak Termohon, produknya berupa putusan dan terhadap putusan tersebut dapat diupayakan banding dan kasasi” (Anonimous, 2010: 54).

Berdasar itu, pihak yang akan menggunakan fasilitas Isbat nikah terpadu harus benarbenar yang melaksanakan perkawinannya secara sah bukan para pihak yang mengajukan secara sepihak (suami atau isteri saja) sebab sangat berpeluang terjadinya nikah sirri dengan motif poligami. Sebab, dalam perspektif global Isbat nikah akan membuka peluang berkembangnya praktek nikah sirri, maka hakim harus mempertimbangan secara sungguhsungguh apakah dengan mengisbatkan nikah tersebut akan membawa kebaikan atau justru mendatangkan madharat bagi pihak-pihak dalam keluarga tersebut (Muchsin, 2008: 21).

Beberapa Pengadilan Agama telah mempraktikan pelaksanaan isbat nikah terpadu, di antaranya Pengadilan Agama Depok, Pengadilan Agama Cianjur dan Pengadilan Agama Karawang di Provinsi Jawa Barat.

Di Pengadilan Agama Depok, Perencanaan isbat nikah dilakukan dalam sebuah rapat koordinasi lintas instansi. Rapat kooordinasi biasanya dilakukan oleh perwakilan dari Badilag, perwakilan dari Kementerian Agama, Ketua Pengadilan Agama, perwakilan dari Dinas Kependudukan dan Catatan Sipil (Disdukcapil) didampingi oleh tim Australia-Indonesia Patnership for Justice (AIPJ), tim dari Pusat Kajian Perlindungan Anak (PUSKAPA) UI, Camat dan staff kecamatan.

Dalam rapat tersebut dibentuk tim tekhnis pelaksana di lapangan mulai dari ketua pelaksana dan tim teknis lainnya. Setelah itu, dibeentuklah kepanitiaan sidang isbat nikah terpadu, kemudian dilakukan sosialisasi program dimulai dengan cara ketua panitia berkoordinasi dengan beberapa kelurahan yang berada di beberapa Kecamatan untuk merekrut peserta dengan beberapa kriteria sesuai dengan Perma Nomor 1 Tahun 2015. Sosialisasi juga dilakukan melalui Web Pengadilan Agama Depok dan Pemda dalam hal ini disdukcapil. Berbagai dokumen yang diperlukan untuk perserta mengikuti sidang isbat nikah terpadu yaitu: a)Foto kopi KTP pasangan suami-istri (2 lembar); b).Foto Kopi KTP wali (2 lembar); c).Foto Kopi KTP saksi-saksi (2 lembar); d).Pas Foto 2x3 (8 lembar); e) Keterangan hari lahir dan 
jam lahir dari desa atau bidan;

Biaya Perkara ditanggung oleh DIPA Pengadilan Agama Depok dan Bantuan Dana dari Pemda (Wawancara dengan Pansek Pengadilan Agama Depok, E. Abdul Fatah 3 Juni 2015).

Inisiatif penyelenggaraan isbat nikah secara terpadu di Pengadilan Agama Cianjur dilakuan oleh Pengadilan Agama, yang dibantu oleh LSM PEKKA yang bekerjasama dengan PEMDA dan Kementrian Agama (Pemda Mengintruksikan ke Disdukcapil dan Kemenag juga mengintruksikan kepada KUA untuk sama-sama ikut andil dalam penyelenggaraan isbat nikah terpadu), kemudian setelah itu PEKKA lah yang berperan aktif dalam menyiapkan penyelenggaraan isbat nikah terpadu seperti mengondisikan konsumsi, lokasi, serta perlengkapan sidang dan perlengkapan yang lainnya yang berkaitan dengan program tersebut.

Secara teknis, persiapan dokumen pelaksanaan isbat nikah terpadu di tiga Pengadilan Agama (Depok, Cianjur dan Karawang) dilakukan sebagai berikut: 1) Pemohon mengajukan permohonan isbat terpadu di daerah hukum pengadilan agama yang meliputi tempat kediaman Pemohon; 2). Pemohon melengkapi persyaratan pengajuan istbat dengan terlebih dahulu membuat surat permohonan (dibantu oleh POSBAKUM), kemudian menyiapkan persyaratan seperti; F.C KTP Pemohon/Para Pemohon, Surat Keterangan tidak terdaftar pernikahan dari KUA, dan SKTM yang diketahui/disahkan sampai tingkat kecamatan (surat permohonan harus melampirkan soft file dalam CD); 3). Berkas pendaftaran tersebut diserahkan kepada petugas Meja 1 Pengadilan Agama, kemudian diberikan nomor perkara dan dibuatkan surat penetapan pembebasan biaya perkara (prodeo). 4). Setalah perkara diterima oleh Meja 1, kemudian panitera melalui petugas meja 1 mengumumkan dalam papan pengumuman yaitu "Masa sanggah" selama 14 hari. 5). Apabila tidak ada sanggahan berkas kemudian diteruskan kepada Ketua Pengadilan Agama melalui panitera. Panitera menunjuk panitera pengganti dan ketua pengadilan menentukan penetapan majelis hakim (PMH). Majelis hakim kemudian menetapkan Penentuan Hari Sidang (PHS), dan memerintahkan JSP untuk melakukan pemanggilan.

Setelah seluruh dokumen permohonan tersebut lengkap dan telah dilakukan pemeriksaan, maka tahap berikuktnya dilakukan pemeriksaan di dalam persidangan dengan tahapan sebagai berikut : a). Pada hari sidang yang telah ditentukan para pihak datang ke ruang sidang 
ljtihad, Jurnal Wacana Hukum Islam dan Kemanusiaan, Volume 17, №. 1, Juni 2017: 113-133

dengan membawa alat bukti tertulis dan saksi-saksi. b). Pemerikasaan perkara dengan hakim tunggal (karena isbat nikah bersifat pemeriksaan administrative). C). Apabila permohonan dikabulkan maka majelis akan akan mengeluarkan penetapan yang ditembuskan ke KUA dan Disdukcapil (Wawancara dengan Panitera Pengganti (Arifin) Pengadilan Agama Depok, 5 Juni 2015);

Tahapan permohonan isbat nikah terpadu karena diajukan secara voluntair proses persidangannya sangat sederhana. Sidang pertama dimulai, setelah dinasehati Majelis Hakim lalu membacakan surat permohonan pemohon, setelah dibacakan atas pertanyaan Ketua Majelis, pemohon menyatakan tetap pada permohonannya, lalu sidang dilanjutkan dengan acara pembuktian. Biasanya acara pembuktian didahului dengan memberi kesempatan kepada pemohon mengajukan bukti tertulis, kemudian pemohon diperintahkan mengajukan saksisaksi.

Uraian di atas menunjukkan bahwa sistem pemeriksaan permohonan isbat nikah adalah bersifat ex-parte. Artinya proses pemeriksaan persidangan hanya sepihak yaitu pemohon sendiri, dan biasanya ada dua pemohon, pemohon I suami, dan pemohon II adalah istri. Tidak ada pihak lain yang bertindak sebagai lawan untuk membantah dalil permohonan. Tidak demikian halnya dalam permohonan pengesahan nikah secara kontentius, yaitu pemohon melibatkan orang lain sebagai termohon misalnya istri terdahulu dan atau para ahli waris suami pemohon. Sistem dan asas pemeriksaannya berbeda. Jika permohonan pengesahan nikah diajukan se-cara kontentius, sistem pemeriksaannya dilaksanakan secara contra-diktoir, asalkan pada sidang pertama atau sidang-sidang selanjutnya dihadiri oleh kedua belah pihak berperkara (pemohon dan termohon) (Harahap, 2013: 69).

Adapun jumlah pihak yang mengikuti isbat nikah terpadu di Pengadilan Agama Depok sebagai berikut: 
Isbat nikah terpadu sebagai solusi memperoleh hak identitas hukum (Ramdani Wahyu Sururie)

Tabel 1

Laporan Pelayanan TerpaduPengadilan Agama Depok Tahun 2015

\begin{tabular}{|c|c|c|c|c|c|c|c|}
\hline \multirow[t]{2}{*}{ No } & \multirow[t]{2}{*}{ Tempat } & \multirow[t]{2}{*}{ Waktu } & \multicolumn{2}{|c|}{$\begin{array}{c}\text { Jumlah } \\
\text { Perkara Isbat } \\
\text { yg Disidang }\end{array}$} & \multicolumn{2}{|c|}{$\begin{array}{c}\text { Jumlah buku } \\
\text { nikah yg } \\
\text { dikeluarkan } \\
\text { KUA }\end{array}$} & \multirow[t]{2}{*}{$\begin{array}{c}\text { Jumlah akta } \\
\text { yang } \\
\text { dikeluarkan } \\
\text { dukcapil }\end{array}$} \\
\hline & & & Kabul & Tolak & Suami & Isteri & \\
\hline 1 & $\begin{array}{l}\text { Kec. } \\
\text { Cinere }\end{array}$ & $06 / 03 / 2015$ & 23 & 2 & 23 & 23 & 45 \\
\hline 2 & $\begin{array}{l}\text { Kec. } \\
\text { Tapos }\end{array}$ & $27 / 03 / 2015$ & 19 & 9 & 19 & 19 & 40 \\
\hline 3 & $\begin{array}{l}\text { Kec. } \\
\text { Bojong } \\
\text { Gede }\end{array}$ & $24 / 04 / 2015$ & 25 & 18 & 25 & 25 & 36 \\
\hline 4 & $\begin{array}{l}\text { Kec. } \\
\text { Pancoran } \\
\text { Mas }\end{array}$ & $29 / 05 / 2015$ & 23 & 5 & 23 & 23 & 45 \\
\hline
\end{tabular}

Sumber: Dokumen Laporan Laporan Pelayanan Terpadu Pengadilan Pengadilan Agama Depok Tahun 2015.

Data di atas menunjukkan bahwa masyarakat yang menggunakan layanan isbat nikah terpadu sesungguhnya cukup banyak. Hal ini mengingat secara hukum bahwa perkawinan sesungguhnya harus dicatat sebagaimana bunyi pasal 2 UU Nomor 1 Tahun 1974. Dengan adanya masyarakat yang menggunakan isbat nikah, di satu sisi menguntungkan bagi masyarakat dengan terpenuhinya identitas hukum mereka namun disisi lain menyisakan masalah, yaitu pencatatan perkawinan menjadi kurang penting. Anggapan bahwa pencatatan hanya administratif belaka menjadi relevan dengan banyaknya masyarakat yang mengisbatkan perkawinan mereka.

Sedangkan di Pengadilan Agama Cianjur, jumlah pihak yang ikut serta di dalam penyelenggaraan isbat nikah terpadu sebanyak 50 perkara yang berlokasi di Balai Desa Cipendawa Kecamatan Pacet Kabupaten Cianjur, pada hari selasa tgl. 16 Juni 2015. Jam 9.00 WIB (Hasil wawancara dengan Wapan PA Cianjur, (Ade Mahmud NH) tgl 31 Juli 2015). 
ljtihad, Jurnal Wacana Hukum Islam dan Kemanusiaan, Volume 17, №. 1, Juni 2017: 113-133

Tabel 2

Laporan Pelayanan Terpadu Pengadilan Agama Cianjur Tahun 2015

\begin{tabular}{ccccccc}
\hline No & Tempat & Waktu & $\begin{array}{c}\text { Jumlah } \\
\text { Perkara Isbat } \\
\text { yg } \\
\text { Disidangkan }\end{array}$ & $\begin{array}{c}\text { Jumlah buku } \\
\text { nikah yg } \\
\text { dikeluarkan } \\
\text { KUA }\end{array}$ & $\begin{array}{c}\text { Jumlah akta } \\
\text { yang } \\
\text { dikeluarkan } \\
\text { dukcapil }\end{array}$ \\
\hline 1 & $\begin{array}{l}\text { Balai Desa } \\
\text { Cipencawa }\end{array}$ & $16 / 06 / 2015$ & 50 & - & 50 & 50 \\
\\
Kec. Pacet
\end{tabular}

Sumber: Dokumen Laporan Laporan Pelayanan Terpadu Pengadilan Pengadilan Agama Cianjur Tahun 2015

Tabel 2 di atas menunjukkan bahwa isbat nikah terpadu di Pengadilan Agama Cianjur baru dilaksanakan satu kali. Namun demikian, pesertanya cukup banyak, yaitu 50 pasangan. Kegiatan tersebut digelar dalam rangka Pelayanan Terpadu pemberian identitas hukum berupa Isbat Nikah, Pencatatan Nikah dan Pemberian Akta Kelahiran. Kegiatan tersebut dimotori oleh sekretariat Perempuan Kepala Keluarga ( PEKKA) Cianjur yang melibatkan Pengadilan Agama Cianjur, Kantor Urusan Agama Kecamatan Pacet Kabupaten Cianjur dan Dinas Kependudukan dan Catatan Sipil Kabupaten Cianjur. Hadir dalam acara tersebut Bupati Cianjur. Tjetjep Mukhtar Soleh, beserta istri, Hakim Tinggi Pengawas Daerah Pengadilan Tinggi Agama Bandung. Adam Murtaqi, Ketua Pengadilan Agama Cianjur, Saefuddin Turmudzy, Kepala Kantor Kementerian Agama Kabupaten Cianjur Dadang Ramdani, Kepala Dinas Kependudukan dan Catatan Sipil Mohammmad Ginanjar, perwakilan seknas PEKKA wilayah Jawa Barat dan perwakilan dari Kemitraan Australia- Indonesia untuk Keadilan (AIPJ ).

Sebanyak 50 (lima puluh) pasangan suami istri yang diisbatkan oleh Pengadilan Agama dan 50 anak yang mendapatkan Akta Kelahiran dari Disdukcapil kabupaten Cianjur. Kegiatan tersebut merupakan realisasi dari program bersama Pengadilan Agama Cianjur, Kantor Kementerian Agama dan Dinas Kependudukan dan Catatan Sipil Kabupaten Cianjur. Pada tahun 2015 ini ditargetkan 350 pasangan suami istri yang akan diisbatkan yang tersebar di seluruh wilayah kecamatan se-Kabupaten Cianjur dan 1050 anak yang akan mendapatkan akta kelahiran (Wawancara dengan Ketua Pengadilan Agama Cianjur). 
Di Pengadilan Agama Karawang, isbat nikah terpadu dilaksanakanpada tanggal 9 Juni 2015 dengan jumlah perkara sebanyak 68 perakara di Kantor Kecamatan Lemah Abang. Dari jumlah tersebut, sebanyak 37 pasangan digugurkan karena mereka tidak hadir. Pernikahan yang diisbatakan rata-rata perkawinan yang dilaksanakan dibawah tahun 2000 (Wawancara dengan Panitera Pengganti Pengadilan Agama Karawang (Ema Sofia).

Pelayanan Hukum Terpadu antara Pengadilan Agama, Kementerian Agama dan Dinas Dukcatpil Kabupaten Karawang digelar dalam rangka kunjungan kerja serta bersamaan dengan kedatangan rombongan Family Court of Australia termasuk diantaranya Departements Of Foreign Affairs and Trade di pimpin oleh Lembaga Australian Indonesia Partnership for Justice, dalam kesempatan tersebut rombongan meninjau sejauh mana pelayanan terpadu yang bisa dilaksanakan oleh Kabupaten Karawang, dimana penyelenggaraannya dalam kategori baik.

Pelayanan terpadu ini antara lain untuk memperoleh Buku Nikah dan Akte Kelahiran yang kegiatannya dipusatkan di Desa Sukakerta Kec. Cilamaya Wetan Kab. Karawang.

Di Pengadilan Agama Cianjur, waktu yang dibutuhkan dalam proses penyelenggaraan isbat nikah terpadu yang dipadukan dengan pelayanan akta kelahiran dari mulai pendaftaran hingga tuntas adalah 1 bulan. Biaya penyelenggaraan isbat nikah terpadu secara prodeo perorangnya sekitar Rp. 131.000.- (seratus tiga puluh satu ribu) dengan rincian, 75.000.untuk proses pemanggilan dan 56 ribu untuk biaya materai (biaya tersebut merupakan bantuan dari DIPA pengadilan Agama yang di Khususkan bagi orang yang tidak mampu).

\section{Analisis}

Isbat nikah terpadu merupakan jawaban atas ketidakpastian hukum tentang perkawinan yang tidak dicatat. Maraknya praktik perkawinan tidak dicatat atau perkawinan bodong sangat merugikan pasangan suami isteri dan anak karena status perkawinannya di mata negara merupakan perkawinan ilegal. Di sisi lain, Isbat nikah sendiri mengandung problem yuridis dan sosiologis. Secara yuridis bahwa pencatatan perkawinan merupakan perintah dari undangundang perkawinan (Pasal 2 ayat (1) sedangkan isbat nikah sendiri memberikan jalan bagi perkawinan yang tidak dicatat dapat menempuh jalan melalui isbat nikah (Penjelasan Umum angka 5 Undang-Undang Nomor 1 Tahun 1974 Tentang Perkawinan). Di sinilah muncul 
ljtihad, Jurnal Wacana Hukum Islam dan Kemanusiaan, Volume 17, No. 1, Juni 2017: 113-133

kontrakdiksi hukum di satu sisi dan solusi hukum di sisi lain. Undang-undang perkawinan hanya mengatur bahwa pengesahan nikah dilakukan terhadap perkawinan (yang tidak dicatat) yang terjadi sebelum tahun 1974. Sedangkan Kompilasi Hukum Islam (KHI) lebih luwes lagi bahkan mengatur lebih rinci alasan-alasan isbat nikah ini sehingga banyak para hakim pengadilan agama yang memeriksa dan memutus perkara isbat nikah menggunakan KHI. Padahal, dari optik ilmu hukum, KHI bukan termasuk salah satu hirarki perundang-undangan. Atas hal inilah Bowen (2001: 10) , misalnya, menggunakan istilah 'validitas ganda' terkait dengan perceraian, dan istilah ini dapat juga dilabelkan pada kasus aturan pencatatan. Dia menafsirkan Undang-undang itu sebagai pertimbangan “... keabsahan negara dan keabsahan agama adalah persoalan yang sepenuhnya terpisah", suatu kedudukan, lanjut dia, diperumit oleh Kompilasi 1991 (Bowen, 2001: 10).

Secara sosiologis, pandangan masyarakat yang mengenyampingkan pencatatan perkawinan sebagai keabsahan nikah yang diikuti dengan perilaku perkawinan tidak dicatat telah menunjukkan gagal faham terhadap makna Pasal 2 Undang-undang perkawinan. Hal inipun dikuatkan dengan bukti empiris mengenai tingginya angka permohonan isbat nikah di Pengadilan Agama berdasarkan Laporan Tahunan Badilag Tahun 2013 dan tahun 2014 bahwa angka permohonan Isbat nikah pada tahun 2013 sebanyak 39.421 dan pada tahun 2014 sebanyak 41,034 (Anonimous, 2014: 42).

Tingginya angka permohonan isbat nikah tersebut menjadi bukti mengenai lemahnya pemahaman masyarakat tentang urgensi pencatatan perkawinan. Berdasarkan studi yang dilakukan oleh Muhktaruddin Bahrum (2013: 214) bahwa alasan Pengajuan Isbat nikah di Pengadilan Agama Sulawesi Selatan adalah nikah sirri yang disebabkan karena berbagai macam faktor. Yakni: a). Faktor fikih sentris dan kurangnya pemahaman mengenai pentingnya pencatatan. Selain itu, sebagian masyarakat muslim berpegang teguh kepada fikih tradisional. Pemahaman mereka bahwa perkawinan sah apabila ketentuan-ketentuan yang tersebut dalam kitab-kitab fikih telah terpenuhi, tidak perlu ada pencatatan di Kantor Urusan Agama dan tidak perlu surat nikah sebab hal itu tidak diatur pada zaman Rasulullah saw. dan merepotkan saja (Manan, 2006: 43); b). Silariang. Faktor nikah silariang, di mana mempelai perempuan tidak mendapat restu dari orang tua atau walinya (Mulia, 2011:24), juga menjadi alasan mengapa perkawinan tidak tercatat. Hal ini dapat dilihat dari penetapan Pengadilan Agama 
Takalar No. 4/Pdt.P/2009/PA. Tkl. Menurut pengakuan pemohon bahwa pencatatan tidak dilakukan karena pemohon dan perempuan tersebut 'silariang', yang dikuatkan keterangan dua saksi bahwa keduanya tidak memiliki buku nikah karena pernikahan silariang.c). Kelalaian imam. Faktor lain yang ditemukan pada lokasi penelitan bahwa penyebab terjadinya nikah sirri karena kelalaian imam sebagai pembantu Pegawai Pencatat Nikah yang tidak menyerahkan data-data pernikahan ke Kantor Urusan Agama, sehingga data perkawinan para pemohon tidak terakomodir dalam buku register perkawinan di Kantor Urusan Agama. d). Pernikahan bukan di depan pejabat resmi. Misalnya pemohon Isbat nikah perkara No. 138/Pdt.P/ 2010/PA. Wtp. melaksanakan perkawinan di muka pejabat. Namun pejabat tersebut bukan pejabat resmi dan sah serta tidak berwenang untuk melaksanakan perkawinan. Hal ini dipahami dari keluarnya duplikat buku nikah tanpa didahului buku nikah asli.

Dualisme hukum mengenai isbat nikah dibiarkan berlalu dengan melahirkan kebijakan baru yang disebut isbat nikah terpadu melalui Perma Nomor 1 Tahun 2015. Secara substantif, sebagaimana telah dijelaskan di atas bahwa terdapat perbedaan antara isbat nikah yang reguler diajukan ke Pengadilan Agama dengan isbat nikah terpadu dari segi proses permohonan, pemeriksaan, biaya dan tempat. Alhasil, isbat nikah terpadu (demikian pula isbat nikah [tanpa terpadu]) telah memberi banyak manfaat kepada masyarakat ditengah ketiadaan dokumen identitas hukum berupa akta nikah sebagai bukti otentik tentang perkawinan, khususnya bagi masyarakat miskin.

Salah satu manfaat dari hadirnya isbat nikah terpadu adalah kemaslahatan. Kemaslahatan merupakan salah satu tujuan hukum Islam. Isbat nikah diatur lebih rinci melalui Kompilasi Hukum Islam. Menurut As-Syatibi (1997: 12) bahwa Allah menurunkan syariat (aturan hukum) tiada lain kecuali untuk mengambil kemaslahatan dan menghindari kemadharatan (jalb almașälih wa dar' al-mafäsid). Dengan bahasa yang lebih mudah, aturan-aturan hukum yang Allah tentukan hanyalah untuk kemaslahatan manusia itu sendiri. Jika dianalogikan, ketentuan mengenai Isbat nikah dalam Undang-Undang Perkawinan dan Kompilasi Hukum Islam tidak lain dimaksudkan untuk lahirnya kemanfaatan atau kemaslahatan bagi manusia.

Ketentuan mengenai Isbat nikah yang tujuannya untuk mencapai kemaslahatan jika dikaji dengan menggunakan teori mașlạ̣ah dan maqāsid shari'ah Al-Syatibi, dapat dirumuskan sebagai berikut: Pertama, bahwa ketentuan mengenai Isbat nikah tidak ditunjukan baik secara langsung 
maupun tidak langsung dalam teks-teks suci (al-Quran dan al-Sunnah), dalam sejarah Islam dan praktik kenabian tidak mengenal itu, sehingga sudah tepat mengkaji permasalahan ini dengan teori maslahah dan maqāsid syari'ah karena salah satu kriteria dari teori maslahah adalah tidak adanya dalil khusus yang menunjukannya. Kedua, bahwa di zaman sekarang dengan jumlah penduduk yang semakin banyak, pendataan berupa pencatatan kependudukan baik itu kelahiran, perkawinan, perceraian, kematian dan lain-lain, mutlak diperlukan. Karena jika tidak dilakukan akan menimbulkan ketidakteraturan dan ketidaktertiban dalam kehidupan bermasyarakat, yang pada akhirnya akan menimbulkan penyelundupan hukum. Dengan demikian ketentuan adanya Isbat nikah bagi perkawinan yang tidak dicatat sesuai dengan maqāsid shari'ah. Ketiga, bahwa dengan tidak dilakukannya pencatatan perkawinan, maka perlindungan terhadap hak-hak anggota keluarga (suami, isteri dan anak) baik berupa hak atas harta, status perkawinan atau pun hak atas identitas diri, tidak bisa diperoleh, sehingga tujuan perkawinan untuk ketentraman tidak terpenuhi, hal itu berarti tujuan primer ad-D berupa hifzal-nasl (memelihara keturunan/ kehormatan) dan hif zal-mal (memelihara harta) tidak tercapai. Dengan demikian pengaturan Isbat nikah bermuara pada menolak kemadharatan/kerugian bagi anggota keluarga dan memberikan manfaat berupa perlindungan hukum atas hak seseorang; Keempat, bahwa Isbat nikah telah memberikan kemaslahatan/keadilan sosial bagi seluruh masyarakat Indonesia secara umum tidak terbatas pada pribadi, agama atau golongan tertentu, oleh karena itu yang ditegakan adalah kemaslahatan umum bukan kemaslahatan individu. Hal itu sejalan dengan kaidah fiqh: (المصلحة العامة مقدمة على المصلحة الخاصة "Kemaslabatan umum (publik.) harus didabulukan daripada kemaslahatan individu” (Djazuli, 2010: 11). Kelima, bahwa secara normatif undangundang perkawinan telah mewujudkan prinsip-prinsip yang terkandung dalam Pancasila dan Undang-Undang Dasar 1945 dan telah menampung segala kenyataan yang hidup dalam masyarakat serta telah mempertimbangkan Hukum Agama Kepercayaan dalam masyarakat, oleh karena itu seharusnya pelaksanaan ketentuan Isbat nikah itu menghilangkan kesulitan masyarakat seperti terjaminnya hak-hak anggota keluarga, sebaliknya tidak boleh menyulitkan masyarakat, baik dari segi biaya, waktu pengurusan, persyaratan dan lain-lain. Karena jika dalam praktiknya untuk sebagian masyarakat ternyata justru menimbulkan kesulitan, karena biaya tinggi misalnya atau karena jauhnya lokasi atau karena halangan hukum (al-man' $)$ lain 
yang tidak bisa dihindarkan, maka harus ada ketentuan alternatif lain, sehingga adanya ketentuan itu tidak merugikan masyarakat.

Berdasarkan uraian di atas, nampak bahwa persyaratan-persyaratan yang ditentukan dalam teori al-maslaḥah al-mursalah terkait penetapan hukum Isbat nikah telah terpenuhi, yakni telah sejalan dan tidak bertentangan dengan maqāsid shari'ah.

Lahirnya kebijakan isbat nikah terpadu telah menegaskan hadirnya negara bagi masyarakat (miskin) yang tidak memiliki identiatas hukum untuk segera memenuhi hak identitas hukumnya berupa akta perkawinan dengan tujuan guna menggapai kemaslahatan bagi mereka sendiri. Jika kebijakan isbat nikah terpadu khususnya bagi masyarakat miskin tidak ada, maka akan menimbulkan kemadaratan sehingga kepastian dan perlindungan hukum bagi masyarakat tidak bisa dipenuhi. Oleh karena itu, isbat nikah terpadu merupakan solusi memperoleh hak identitas hukum bagi masyarakat yang tidak mampu.

\section{Penutup}

Berdasarkan uraian di atas dapat dikemukakan kesimpulan sebagai berikut: Pertama, dasar hukum isbat nikah terpadu adalah Peraturan Mahkamah Agung Nomor 1 Tahun 2015 tentang Pelayanan Terpadu Sidang Keliling Pengadilan Negeri dan Pengadilan Agama/ Mahkamah Syar'iyyah dalam Rangka Penerbitan Akta Perkawinan, Buku Nikah dan Akta Kelahiran. Nampak dari substansi Perma tersebut pengaturan Isbat nikah terpadu dilakukan dengan prinsip pelayanan mudah, yaitu mampu mengatasi birokrasi kepemilikan hak identitas hukum yang berbelit-belit dengan kemudahan layanan melalui keterlibatan birokrasi terkait, yaitu Pengadilan Agama, KUA dan Disdukcapil. Selain itu, terdapat juga terobosan hukum yang dimiliki oleh Perma ini yaitu hakim yang memeriksa perkara Isbat nikah dibolehkan dengan hakim tunggal dan jurusita dapat melakukan panggilan secara kolektif.

Kedua, latar belakang pemberlakukan isbat nikah terpadu karena minimnya masyarakat mengakses layanan memperoleh identitas hukum padahal dokumen identitas hukum tersebut sangat penting bagi akase pada layanan lainnya berupa askes pada pendidikan, kesehatan dan ekonomi. Tanpa identitas hukum berupa akta nikah, seorang anak tidak akan memperoleh akta lahir dan pasangan suami isteri tidak bisa menyekolahkan anaknya dan seterunya. Sedangkan tujuan dari isbat nikah terpadu ini sebagai bentuk tanggungjawab negara memberi 
ljtihad, Jurnal Wacana Hukum Islam dan Kemanusiaan, Volume 17, No. 1, Juni 2017: 113-133

kepastian dan perlindungan hukum bagi masyarakat. Selain itu, isbat nikah terpadu memberi kemaslahatan dan kemanfaatan bagi pasangan suami isteri;

Ketiga, proses isbat nikah terpadu berkaca pada pengalaman beberapa Pengadilan Agama menunjukkan bahwa isbat nikah terpadu dilaksanakan secara cepat dengan prinsip one day one service. Hakimnya tunggal, proses pemanggilan secara kolektif, tempat sidang fleksibel dan biaya gratis merupakan jenis pelayanan yang diberikan negara kepada masyarakat dengan pola integarted service (layanan terpadu) atara Pengadilan Agama, KUA dan Disdukcapil.

Keempat, atas terselenggaranya isbat nikah terpadu ini hak memperoleh identitas hukum berupa akta nikah menjadi mudah diperoleh/dimiliki sehingga isbat nikah terpadu merupakan solusi yang diberikan negara kepada masyarakat memperoleh kepastian hukum.

\section{Daftar pustaka}

Ade Mahmud. NH,. Hasil wawancara dengan Wapan PA Cianjur, (Ade Mahmud NH) tgl 31 Juli 2015. Jam 16.00 s/d 17.00 WIB).

Al-Shatibi, Abu Ishaq. Al-Muwafaqat. Beirut: Dār al Ma'rifah, 1997.

Amin, Mawardi. Kepastian bukum Isbat Nikab Terbadap Status Perkawinan, Status Anak Dan Status Harta Perkawinan (Penelitian Asas, Teori, Norma dan Praktik Penerapannya Dalam Putusan Pengadilan). Jakarta: Puslitbang Kumdil, 2012.

Anonimous. Buku II tentang Pedoman Pelaksanaan Tugas dan Administrasi Peradilan Agama. Jakarta: Badilag 2010.

Anonimous. Laporan Tabunan Badilag Tahun 2013. Jakarta: Dirjen Badilag, 2013.

Anonimous. Laporan Tabunan Badilag Tahun 2014. Jakarta: Dirjen Badilag, 2014.

Bahrum, Mukhtaruddin. "Legalisasi Nikah Sirri melalui Isbat Nikah Menurut Kompilasi Hukum Islam”, dalam Jurnal Diskursus Islam Vol. 1 No.2, Agustus 2013.

Djazuli, A. Kaidah-Kaidah Fikih: Kaidah-Kaidab Hukum Islam Dalam Menyelesaikan MasalahMasalab Yang Praktis. Cet. ke-3. Jakarta: Kencana, 2010.

Farida, Maria. Ilmu Perundang-Undangan. Yogyakarta: Kanisius, 1998.

Harahap, M. Yahya. Hukum Acara Perdata, Gugatan, Persidangan, Penyitaan, Pembuktian, dan Putusan Pengadilan. Jakarta: Sinar Grafika, 2013.

Hurairah, Abu. "Hakikat Isbat Nikah dalam Sistem Hukum Perkawinan Indonesia", Disertasi. Makassar: Program Pascasarkana Universitas Muslim Indonesia, 2015.

Husaini, Muh. Irfan. "Mengapa Pemeriksaan Perkara Isbat Nikah di Luar Pengadilan Harus Terpadu" dalam www.badilag.net, diakses 2 Februari 2016. 
Isbat nikah terpadu sebagai solusi memperoleh hak identitas hukum (Ramdani Wahyu Sururie)

Bowen, John. Shari'a, State, and Social Norms in France and Indonesia. Nether-land: ISIM, 2001.

Manan, Abdul. Aneka Masalah Hukum Perdata Islam di Indonesia. Jakarta: Kencana Prenada Media Group.

Muchsin. "Problematika Perkawinan Tidak Tercatat dalam Pandangan Hukm Islam dan Hukum Positif”, dalam Materi Rakernas Perdata Agama. Jakarta: Mahkamah Agung RI. 2008.

Mulia, Siti Musdah. Membangun Syurga di Bumi Kiat-kiat Membina Keluarga Ideal dalam Islam. Jakarta: PT. Elex Media Komputindo, 2011.

Pangabean, Henry P. Fungsi Mabkamah Agung dalam Praktik Sehari-Hari. Jakarta: Sinar Harapan, 2001.

Sumner, Cate. Studi Dasar AIPJ Tentang Identitas Hukum Jutaan Orang tanpa Identitas Hukum Di Indonesia. Jakarta: DFAT (Australian AID), 2013. 